Slobodan K. Grubačić*

profesor emeritus, Univerzitet u Beogradu, Filološki fakultet

\title{
ORFEJ U PRAGU: LUTKA I ANĐEO U POEZIJI RAJNERA MARIJE RILKEA
}

Zamršeni pisani znaci intertekstualnosti - kako glasi jedna fraza Petera Handkea - pokreću analize u ovom prilogu. Otuda je pristup komparatistički. Devinske elegije, u kojima je Rilke video svoje najkrupnije pesničko dostignuće, izgledaju kao konglomerat simboličkih predstava i rasutih kulturoloških asocijacija. Sve one kruže oko zagonetke životnog smisla. Čovek je sam; krug se nigde ne zatvara. Naša je sudbina da težimo preobražaju, tj. oslobađanju individualnosti. Soneti posvećeni Orfeju variraju slične misli koje simbolima povezuju „nevidljive anđele" sa slikama lutke, marionete.

Ključne reči: simboli akrobate, lutke i nevidljivog anđela; čulno predočavanje; „unutarnji prostor sveta“; plastična snaga uobrazilje: vidovi preobražaja; cirkus kao apokalipsa srednjoevropske duše.

Zagonetni pesnik čiji lik je bio crtan, vajan i slikan na prozorskim oknima - od Amsterdama do Kronštata - taj pesnik koga vole pesnici, pisac u večnom pokretu koji je pevao na tri jezika, a nikada nije plovio samo jednom strujom, pokazivao je ne samo dve osnovne opreke $\mathrm{u}$ svom književnom ispoljavanju, ekstazu i skepsu, već i dva suprotna vida ljudske prirode: vidljivo-nevidljivo, zanosno-trezveno.

Oba su prisutna i kod drugih pisaca, na primer kod Tomasa Mana ili Andrića, ali se kod Rilkea javljaju istovremeno, 1922, u trenutku velikog „proloma“, kako ga pesnik naziva: u trenutku nastanka šest poslednjih elegija u jednom malom zamku (Château Muzot) u švajcarskom kantonu Valisu. „Sve u nekoliko dana, bila je to bezimena oluja, orkan u duhu“, pisao je svom izdavaču Kipenbergu 9. februara iste godine ovaj zaljubljenik u tvrđave i zamkove, „milujući pritom“, u sećanju, i „zidove dvorca u Devinu“ kraj Trsta, razrušene u Velikom ratu (Rilke 1934: 355).

Iza Rilkeove Pete Devinske elegïe stoji doživljaj Pikasove slike Artisti (Les Saltimbanques) (Starobinski 2004: 114), koja je visila u pariskom stanu pesnikinje Herte Kenig (König), u vreme kada je Rilke bio njen gost u Parizu 1915. Krupno Pikasovo platno pokazuje čuvenu trupu „Rolins“, koja je nastupala u Luksemburškom parku u Parizu 1907. godine, na istom mestu gdje je, u vreme Francuske revolucije, mesecima bio zatočen portretista Žak-Luj David, i gde je, stojeći iza prozora Luksemburške palate, slikao svoj jedini pejzaž - park u kome

bobo.grubacic@gmx.net 
je priroda ukroćena i uređena, ali su krošnje drveća ipak spojene, prepletene u svom neukroćenom duhu. A ispred legendarne palate ukazivao se, već dugo, suprotan prizor - šarena slikovnica, vašarište, eksplozija života, dovikivanje dece i nastupi akrobata.

Takav je akrobatski performans video i Rilke, ali ga je tek Pikasova slika potakla da napiše pesmu Grupa (Die Gruppe, 1908), koja se sastoji samo od jedne rečenice. Potpuno novu viziju istog događaja imaće, potom, Rilke u pomenutoj Petoj Devinskoj elegiji koja liči na film sa pokretnim Pikasovim slikama. To je ono što će zaprepastiti čitaoce. Elegija će raščarati cirkuski svet i začarati čitaoce.

Pokreti akrobata sada razotkrivaju „obeskorenjenu“, lebdeću egzistenciju artista kao takvu. Ne samo onu spoljašnju, nomadsku, nestalnu i „putujuću“, uvek na točkovima. Nego i onu unutarnju, dubinsku, koja i ne krije koliko je njihovo biće prožeto patnjom, prazninom i - besmislom. Onu što podseća na lepu metaforu koju pominje Bodler u eseju o Edgaru Alanu Pou. U njemu pesnik Albatrosa govori o tome kako pojedini pesnici, u svojoj „genijalnosti“, polaze od pretpostavke da će ih, nakon bacanja slova u vazduh, dočekati na zemlji gotove pesme.

Ponavljanje njihove tačke stalno budi svest o prolaznosti, o tome da je ova njihova sadašnjost jednom bila budućnost i da će se jednom zvati prošlost. Likovi artista su u Rilkeovoj elegiji beživotne lutke, igračke patnje. Duboko u senci tanatosa, oni su plen privida, robovi jedne besmislene sudbine zarobljene u ritualu. Svu aktivnost ovih lutalica, umetnika nomada, „putnika prolaznijih i od nas samih“, određuje pritom - kako tvrdi pesnikovo lirsko ja - neki skriveni animator koji ih koncima pokreće. Neka nevidljiva tuđa „volja“ što se uporno i vešto krije iza akrobatskih majstorija koje nisu ništa drugo do trivijalnost, šablon, besmisleni kovitlac.

Al' ko su zaista, reci, ovi putnici, malo prolazniji i od nas samih, oni koje od ranog časa, užurbano, uvrće - kome, kome za ljubav neka nikad zadovoljna volja? Već ih uvija, zavrće, u čvorove svija i vitla, baca ih, pa ih hvata; i oni padaju kao iz nauljenog, glatkog vazduha na već otrcani, od večitog njihovog skakanja sve tanji tepih, ovaj tepih izgubljen u svemiru.
Wer aber sind sie, sag mir, die Fahrenden, diese ein wenig

Flüchtigern noch als wir selbst, die dringend von früh an, wringt ein - wem, wem - zu Liebe niemals zufriedener Wille? Sondern wringt sie, biegt sie, schlingt sie und schwingt sie, wirft sie und fängt sie zurück; wie aus geölter, glatterer Luft kommen sie nieder auf dem verzehrten, von ihrem ewigen Aufsprung dünneren Teppich, diesem verlorenen Teppich im Weltall (Rilke 1975b: 701). 
Tepih, prostirka na kojoj ovi „prolazni putnici“ izvode veštine, postaje sve tanji zbog zaleta i „večitog njihovog skakanja“.. Kao realnost, tepih se pominje već u Rilkeovom zapisu o akrobatama (Saltimbanques) iz 1914. Ali ta iskrzana prostirka ovde dodatno postaje simbol: postaje „tepih izgubljen u svemiru“. Ne kao neki čarobni leteći ćilim, već upravo suprotno: kao oličenje nesigurne egzistencije koja se - tanji. Pesnik u svakom trenutku zna da je veština artista samo bolna iluzija. Zna da stvarne, egzistencijalne baze nema, i da, u stvari, pre prvog skoka, kao i nakon poslednjeg doskoka, traje unedogled ta večnost obeskorenjenosti, taj usud bezdomnosti i suštinskog nepostojanja ovih „palih ljudi“, čiji zaleti i skokovi jurišaju, kao drhtaj, jedni iza drugih, da bi na kraju stali tamo gde tlo nestaje, čili. Gde je sve svedeno na najmanje razmere, na trošni, pokidani tepih koji postaje sve tanji. To je „večnost“ jedne aktivnosti koja zapravo nema nikakav smisleni cilj.

Analogno mesto kod Ive Andrića takođe govori o promenama i preobražajima. To što u svakodnevnom životu gledamo oko sebe i čime se stalno služimo, što nazivamo „prostirka ili pod“, kaže pisac Znakova pored puta, to je jače od sudbine. To

počne brzo i tajanstveno da se preobražava, da se menja i vraća u prvobitno stanje, i da postaje opet bezoblična, bezimena materija [...] Tako nam se priviđa svet oko nas, dok, u stvari, to mi ubrzo umiremo u sebi (Andrić 1981c: 242).

Cela šarolika predstava njiše se i podrhtava pred pesnikom kao providni veo, iza kojeg lirski subjekt vidi i ono šo ne želi da vidi. U njegovoj svesti iskrsava misao, jasna i munjevita, kao otkriće. To je misao o jednom svetu artizma označenom kao sfera zajednički sazdanih pokreta, u kome, uprkos ritualnoj preteranosti, uprkos savršenstvu, umetnici padaju i stradaju kao probuđeni mesečari.

Njihov svet izgleda tesan i strašan. To je bezdan iz čijih dubina odzvanja glas o savršenoj izolaciji, o nedostatku komunikacije sa okolnim svetom, koji Žorž Pule, govoreći o Rilkeovoj poeziji, označava kao prostor u kome se svi doživljeni trenuci ravnodušno raspoređuju „kao zvezde, i nastavljaju da žive, svaka u svom sjaju, stalnim i istovremenim životom" (Poulet 1961: 162). Ubrzo će uslediti još neveselija slika otuđenosti u liku „svelog starca“ koji se opire, zgrčen u svojoj prevelikoj koži, „što kao da je ranije dva čoveka sadržala“, pa jedan leži na groblju, a ovaj ga je preživeo, „gluv i smušen u svojoj koži““ (Rilke 1975b: 702).

1 Pri citiranju pesama sledimo izvrsne prepeve Branimira Živojinovića, osim na mestima gde odstupaju od izvornog smisla. Rilke R. M. (1968). Lirika. Beograd: Prosveta. 
Paralelne slike marionetske sudbine ponovo se prepoznaju i kod drugih autora. Nama je zanimljiva ona u zapisima Ive Andrića. To je opis čoveka koji takođe izgleda kao da mu je neko zašio telo „u neku tuđu preširoku kožu, oživeo i stavio ponovo u kružno kretanje živih bića“" (Andrić 1981d: 174).

Ta ljudska granica, naizgled elastična i dovoljno široka, dozvoljava čoveku rast, ali mu ne da van. Na telu koje se zove njegovo - sve je manje njegovog. Čovek je bespomoćna lutka: neka nepoznata sila, fantom, demijurg, baca ga, vitla i povlači konce, i sve čini da ga besmislenim akrobacijama pretvori u klupko jada, pretvorivši usput i ceo svet u pozorišni fundus, iz kojeg svako uzima rekvizite po svojoj želji.

Čudesni su zajednički elementi. Opet Andrić kaže da „Neko ili nešto“, bez vidljiva razloga „podiže ljude od zemlje, trese njima, pa ih baca na zemlju“, i oni poskakuju „u stalnoj borbi sa Zemljinom težom“ (isto: 464). Primetno je, takođe, koliko se Andrićeva poetika protivi „najuzaludnijoj“ od svih „prikazivačkih“ umetnosti - jednoj umetnosti sačinjenoj od kartonskih kulisa, naslikanih ovlaš. Koliko se protivi toj vrsti čulnog prikazivanja podjednako dalekog „od varke kao i od stvarnosti“ (Andrić 1981b: 12), dok je u isti mah njegov diskurs potpuno u njenoj „varljivoj“ vlasti čulnog dočaravanja.

A to je samo još jedan element koji povezuje Andrića i Rilkea. Jer, mada iz drugog ugla posmatrana, sudbina artista i ontološka dubina neminovnog pada čine sada razumljivijim i one slike kojima Rilke dokazuje da se akrobatska umetnost, pa i svaka druga „prikazivačka“ umetnost, odvija nad metafizičkim ponorom.

U taj morbidni ponor pesnik u pretposlednjoj strofi povlači sve: „bekrajno pozorje Pariza“, na kome modistkinja „madam Lamor“ („Madame Lamort“: gospođa smrt) vezuje i spliće „sve nemirne zemaljske puteve" u beskrajne trake. Od njih stvara nove mašnice, nabore, cveće, kokarde i veštačko voće - „sve to lažno obojeno“ - za jevtine zimske „šešire sudbine“. Sve se tu menja i ponavlja. Površan i lažan nije samo veštački osmeh akrobata i njihovo umeće, njihova besmislena parterna gimnastika. Površan je i sam privid koji briše za sobom sve, pa i najtvrdokorniju stvarnost, dok svoje kulise i priviđenja gradi ni na čemu. Tačnije, na nekom kosmičkom tepihu, „izgubljenom u svemiru“, kako ga prva strofa i označava. Na tlu koje je sam stvorio (Rilke 1975b: 701).

Usamljenost, pak, Rilkeovih artista može se meriti samo s izolacijom Kafkinog „umetnika u gladovanju“ u istoimenoj priči (1917). Umetnika dobrovoljno zatvorenog u kavez - najpre ponosnog, a potom ravnodušnog, koji predstavlja atrakciju svojom izdržljivošću koja postaje samoj sebi svrha. Uprkos svemu, njegov paradoksalni 
optimizam okrutniji je od Rilkeovih elegija. Jer u njima se, na kraju, „uz tupi pljesak“, posle nekoliko suza, „hitro u oči nateranih“, ipak pojavljuje „osmejak“. To je „osmeh skakača“: Subrisio Saltat. I to je slika sa kojom pesnik prepušta sudbinu akrobata nevidljivom anđelu.

Anđele! O, uzmi, uzberi tu sitnocvetu Lekovitu biljku. Nabavi vazu, u njoj je sačuvaj! Stavi je među one Radosti što za nas još nisu otvorene, U ljupkoj je urni veličaj cvetastim Zanosnim natpisom: „Subrisio Saltat“.
Engel! o nimms, pflücks, das kleinblütige Heilkraut.

Schaff eine Vase, verwahrs! Stells unter jene, uns noch nicht offenen Freuden; in lieblicher Urne rühms mit blumiger schwungiger Aufschrift: „Subrisio Saltat“ (Rilke 1975b: str. 703).

Uzimanje lekovitog cveta, tog famoznog leka iz priručne apoteke duše, povereno je nevidljivom liku anđela. To opasno širi raspon „psihičkog klatna“ u lirskom subjektu, ali donosi i dragoceni preobražaj, neophodnu ravnotežu. Donosi „gravitaciju“ kao metaforu bivstvovanja. Zašto je taj učinak tako važan? Egzistencijalni položaj čovekov u borbi s okovima života moguće je sagledati samo kao ukupnost, kao jedinstvo uspona i pada, zanosa i sunovrata, nastajanja i nestajanja. U pismu prevodiocu Vitoldu Huleviču 15. 11. 1925, dve godine nakog objavljivanja Devinskih elegija, Rilke govori o tom velikom jedinstvu: „Nema ni ovog ni onog sveta, nego postoji veliko jedinstvo, u kojem borave bića koja nas nadmašuju, 'anđeli'“ (Rilke 1937: II, 900).

Šetajući po liticama iznad Jadranskog mora, Rilke je u snažnom huku istarskog vetra čuo prvi stih svojih Elegija: „Ko bi, da kriknem, ko bi me čuo iz četa anđeoskih?" (Rilke 1975: 685) Niko ga, doduše, neće čuti ni docnije, u noćima u kojima ce pevati jureći, lutajući, vrišteći po praznim odajama zamkova svojih aristokratskih mecena u tršćanskom Devinu (Duino) i valisovom Mizu (Château de Muzot, Kanton Wallis), okružen tornjevima i zidinama „što liče na ogromno telo bez mnogo duše“ (isto).

Bila je to njegova lična drama, pozorje u kome je bio glavno lice i jedini gledalac. Drama zaoštravanja socijalne nevolje i ozbiljnih psiholoških problema kao što su gubitak identiteta, osećanje otuđenosti, ali i napor da se zaštiti od okrutnosti sveta i svojih sopstvenih demona. Sa svim znacima samotničke genijalnosti, Rilke je melanholičnim šiframa opisao svoju egzistencijalnu potresenost. Nikad u njemu neće više biti tako jako izraženo istovremeno osećanje bukvalnog i transcendentalnog beskućništva. Ali koje anđele je prizivao?

Njegovi anđeli nemaju nikakve sličnosti s Ognjenim anđelom ruskog simboliste Valerija Brjusova, romanom prevedenim u to vreme 
na nemački (1910), pa ni s anđelima drugih evropskih simbolista. Ali ce zato, iako „nevidljivi“, astralni i bestelesni, ostaviti traga u likovnoj umetnosti. Najpoznatiji su na slikama Edvarda Pointera i Paula Klea. Rilke će, doduše, snažno uticati na čuvenu Odenovu zbirku U ratnim vremenima (In Times of War) (1939).

Ali - to nisu isti anđeli. Tačnije, izričit je Rilke, to nisu anđeli hrišćanskog neba. Budući bestelesni, oni ne poprimaju oblik po zakonima sveta. Ne izgledaju kao da su došetali na visokim koturnama i s raširenim krilima. Nemaju ni oči „brata anđela“ iz pesme Kalenić Vaska Pope. Ne izgledaju kao zlatni oblak u Nazorovoj priči Anđeo u zvoniku ${ }^{2}$, a ponajmanje nalikuju moćnom vasionskom talasu i „olujnom zvuku-sjaju“ vatrenog, svetlonosnog stuba kod Andrića (Andrić 1981c: 545).

To su nečujne lutalice kroz vreme i svetove; nebeske sile što nemilice uništavaju izvore ekstaza i bezumlja. Očigledno je, ipak, da blagonaklono prate stvorenja u kojima je već izvršen preobražaj vidljivog $\mathrm{u}$ nevidljivo. Prisutne u književnosti još od Homera, one su i ovde „glasnici“. Kao posrednici otkrovenja, nose jasnu poruku: naša je sudbina da stalno težimo preobražaju, da uporno probijamo statiku postojanja. „Da, naš je zadatak“, kaže Rilke u pismu prevodiocu Huleviču, „da ovaj prolazni i trošni svet tako duboko, tako sapatnički i strasno utisnemo u sebe da njegovo biće 'nevidljivo' uskrsne u nama“ (Rilke 1937: II, 901). Više je nego očigledno da se taj „preobražaj u nevidljivo" manje odvija u analogiji sa Ničeovom završnom fazom triju metamorfoza, a više sa slikom „trostrukog rađanja“ mistika Jakoba Bemea: sa trećim, nevidljivim, razvija se čovek koji je zreo za sva tri rođenja.

Tako su, kaže Rilke u pomenutom pismu, za anđela iz njegovih elegija sve nestale kule i palate postojeće - zato što su odavno nevidljive. A još postojeće kule i mostovi iz našeg života već su nevidljivi, iako (za nas) još telesno traju. Anđeo iz Elegija, zaključuje Rilke, ,jeste ono biće koje se zalaže za to da se u nevidljivom svetu spozna viši stepen realnosti“ (isto). Taj napor iziskuje strahovita odricanja i to je, po svemu sudeći, razlog zbog kojeg anđela naziva - strašnim. Svaki je anđeo strašan, tako glasi početak Druge elegïje. „Pa ipak, jao meni, / ja vas opevam, gotovo smrtonosne / ptice duše, a svestan sam šta ste vi“ (Rilke 1975b: 689).

A oni doista i jesu ono što spaja lepo i strašno. Neobični spoj pripisan je, sledstveno, bićima s najbizarnijim atributima. U njima se sve otima da izrazi i fiksira krajnost. I to krajnost kao takvu. Treba samo pogledati one koje, na istom mestu, nabraja sledeća strofa. To su: „prostori suštog bića“, „miljenici stvaranja“, „visijski venci“, „štitovi miline“,

2 Nazor, V. (1927). Priče s ostrva, iz grada i s planine. Zagreb: Matica hrvatska. 
„jutarnji rumeni grebeni sveg začinjanja“, „vreva olujno ushićenog osećanja“, „poleni cvetnog božanstva“ i najzad - „ogledala“. Čarobna ogledala koja odražavaju celu tu barokno raspevanu lepotu, ali i celu tu dvostruku težnju za ulivanjem sveta u sebe i izlivanjem sebe u svet: „Ona svu lepotu što struji iz njih, / ponova unose u lice sopstveno“ (isto).

Tropi i zeugme se kod Rilkea neočekivano osamostaljuju. Ne znamo koja će se asocijacija značenja ostvariti u daljem toku pesme. Stvar je utoliko paradoksalnija jer je opšta odlika anđela upravo ta - da se ne mogu definisati rečima. U tom pogledu je pesnik, svesno ili nesvesno, ipak ostvario svoj mogući cilj: „Sve želi da lebdi“ (,Alles will schweben“), kažu njegovi Soneti posvećeni Orfeju (isto: 760).

I poetske činjenice počinju da lebde i njihov lebdeći smisao gradi sistem svojih univerzalija: jedan novi poredak poetskih zakonitosti što se prelamaju u pojedinačnim zbivanjima i individualnim sudbinama. Kako bi to rekao formalista Mukaržovski: semantička analiza može samo da nagađa koliki je stepen prenesenog smisla pojedinih reči (Mukařovský 1948: 12). Utehu je tumačima svojevremeno davao Škreb: bliske zagonetkama, one su i stvorene ne zato da budu rešene, nego da svojom zagonetnošću deluju umetnički (Škreb 1976: 137).

Molitve, ispovesti, marijanske pesme, anđeli, hristološke vizije Rilke ih oslobađa iz tradicije i unosi u svoju ličnu mitologiju, još bolje - u svoju ličnu imagologiju, svesnu posebnih samozakonitosti, toliko posebnih, da još uvek ne jenjavaju tumačenja koja mu pripisuju ateizam i anarhizam.

Horror angelorum: angelološke paradigme, slike monade i raspetog serafa Rilke prenosi iz transcendencije i bez naprslina spaja $u$ stilsko jedinstvo, pretapa u svoj „unutarni prostor sveta“. Taj prostor doista raste s prodorom dionizijskih sila do neočekivane i veoma suptilne svetovnosti. Širi se i smisao poetske reči, stvaraju novi spojevi, sintagme, složenice, što sa sobom nosi mnogo toga: promene značenja, inverzije: svet uzajamne zamene svega suštinskog.

Zvuči kao banalni biografizam, ali do promena dolazi i u sferi ovozemaljske ljubavi. Lu Andreas Salome (Tebi u slavu!) otkrila mu je onaj suštinski, „unutarnji prostor“ njegovog pesničkog carstva, njegovu „unutarnju“ Rusiju koja se širi i rasplinjava u beskonačnom. Ima ga, otuda, najviše kod onog Rilkea koji, umoran od Evrope, putujući po Rusiji zajedno sa Lu Andreas Salome, pobožnom i amoralnom u isti mah, kleči obeznanjen pred pravoslavnim ikonama.

Otkrila mu je, na kraju, i usamljenost, osećanje napuštenosti. Najavila je i da nijedan pesnik $\mathrm{u}$ istoriji neće poneti takav krst. Tokom decenija samoizgnanstva Rilke je magično privlačio duhovnu i društvenu aristokratiju Evrope i bežao od njih kao progonjena zver, a talasi iracionalnih, duboko emotivnih reakcija izbacivali su znakove 
proviđenja i rađali narative o čudesnom rasporedu zvezda sklopljenom nad njegovom sudbinom.

Sudovi o suštini božanskog kod Rilkea, o njegovoj religioznosti i „mistici“ veoma se razlikuju. Jedni tvrde da njegovo istupanje iz katoličke crkve počiva na pukoj predrasudi, drugi ga smatraju za panteistu u smislu obožavanja prirode i osećanja Jedinstva i Celine u pesničkoj tradiciji jednog Getea. O tome Jednom i Sveobuhvatnom takođe ne postoji nikakav pojam, niti se o njemu išta može reći, jer je iznad svih određenja. Najzad, neki ga vide, zajedno sa Martinom Hajdegerom, kao „divinatora“ svega konačnog, trošnog i smrtnog, i pritom navode oduševljene sudove ovog mislioca, koji celu svoju filozofiju identifikuje sa Devinskim elegijama (Graff 1962: 172).

Ali, šta predstavlja pojam „nevidljivog”? I zaštoje opisan još „,nevidljivijim“, neprozirnijim epitetima? Rilke, videli smo, gradi novu kosmologiju. U Sonetima posvećenim Orfeju, potaknut je, tačnije - nateran nepodnošljivim udarima „tučanog zvona što svoje klatno svakodnevno diže protiv tupe svagdašnjice“ (Rilke 1975b: 766). Zaista je teško naći veći kontrast u odnosu na ono Bodlerovo blaženo zvono, čiji naprsli zvuk budi nostalgična sećanja: „Kako se daleke uspomene uzdižu / Uz zvuk zvona koja pevaju u magli“ (Naprslo zvono / La Cloche fêlée iz zbirke Cveće zla / Les Fleurs du Mal: „Les souvenirs lointains lentement s'élever / Au bruit des carillons qui chantent dans la brume“).

Nema glasnijeg „idiofona“ od tučanog zvona. Ni trajnijeg. Njegovi zamasi nalaze i kod Rilkea i kod Andrića svoj pesnički izraz u potresima, u motivu drhtanja, uznemirenosti, disanja i damara srca. „Moja duša je hrana za zvono, i Bog je dovodi do belog usijanja“, kaže, na primer, Rilke u pismu upućenom Lu Andreas Salome, ali onaj proces pretvaranja zvona u nevidljivo nikako da se završi: ,ja sam još uvek samo njegov stari kalup, koji je već odradio svoje, zbog čega ostajem neizliven“ (Rilke/Salomé 1952: 353).

I kao što kod Andrića sve vidljivo postaje bezimeno (Andrić 1981d: 262), tako se ovde vidljivo preobražava u akustično - u motiv zvona i zvonjave. A upravo je on posebno pogodan da izrazi taj nezavršeni prelaz u „nevidljivo“. U Rilkeovim Sonetima posvećenim Orfeju, zvono je "tihi drug dalekih vidika / međ gredama mračnoga zvonika“ (XXIX) (Rilke 1975: 770). O tome neposredno govori Rilkeova Deseta elegija. Iz lažne empirijske stvarnosti, iz „kalupa praznine“ i cele te „od zaglušenosti načinjene tišine“, ispao je, kaže pesnik, „odlivak“ autentičnog života (Rilke 1975: 721). Stoga je nužno povlačenje u zaštićeni prostor nutrenosti.

Nema u meni čvrstog jezgra: ja sam puko poprište jednog niza unutarnjih susreta, prolazni hodnik, ali ne i kuća! A hteo bih da se nekako 
dublje povučem u neki manastir, u kome vise velika zvona (Rilke/Salomé 1952: 97).

Tu se desio preokret. U elegiji je pala ključna reč o nevidljivom, „unutarnjem prostoru sveta“ koji se ujedno pruža kroz sva bića i sve stvari na zemlji. Ima ga, međutim, i u pesmama iz septembra 1914 (Rilke 1975c: 93). Zagonetan, nesvodiv, taj „Weltinnenraum“ od svog nastanka predstavlja i najveći izazov za sve hermeneutičare sveta koji osećaju da im se pesnik obraća jezikom duboke mudrosti. Ima iskustava koja nas nagone da sve iznova proverimo, i takvo jedno iskustvo bio bi osvrt na važnu Geteovu sintagmu. Možda bi se refleksija o unutarnjem svetskom prostoru mogla povezati i sa „večnom“ Faustovom težnjom koju iskazuje već u prvom monologu čuvene drame, sa težnjom da konačno spozna šta se krije u suštinskom središtu sveta („Was die Welt im Innersten zusammenhält“). Izvesno je samo da Rilkeov „unutarnji prostor sveta“ označava mnogo toga: praosnovu života, smisao i zalogu bivstva, svemir u sebi, najdublju suštinu ličnosti, suštinu bića.

U tome nije bio sam. Jer, ako se igde može govoriti o nespornim podudarnostima - a može, i to argumentovano i ubedljivo - onda se one mogu naći u Andrićevom analognom bekstvu od konkretne stvarnosti i okretanju bezglasnim i „bezimenim suštinama”. O njima je reč u Znakovima pored puta (Andrić 1981d: 262). Tamo gde njihov autor objedinjuje produhovljenost svojih dela u estetskom idealu nevidljivog i „nepostojećeg“ (Andrić 1981a: 15). Jer, kao i Andrić, unoseći elemente mistike u gusto naslagane vrednosne slojeve svoje poezije, Rilke takođe govori o tom „unutarnjem svetskom prostoru“ (Weltinnenraum) kao o fenomenu „bezimenom“ i „nevidljivom“ (Rilke 1975b: 93).

Paradoks je u plastičnoj snazi njegove uobrazilje. U tome što za imenovanje nevidljivog unutarnjeg sveta iz čudesne kutije metafora vadi jarke boje što se rasplamsavaju kao „vatra duše“, slivajući se u „nezemaljskom bunilu“ jedna s drugom u srebrnim zvucima zvona, ili se rasplamsavaju u tamnoplavim dubinama neba, čarobne kao „plamene ruže“ (Rilke 1975b: 128).

U njima se, ipak, može prepoznati njegov krajnji cilj. I to kroz fonocentrični obrt, jer taj nevidljivi, unutarnji prostor je i „ozvučen“. To je kliktaj samospoznaje, najavljene već u prvom stihu završne elegije: „Da jednom, na ishodištu viđenja jarosnoga, uskliknem slavu i hvalu saglasnim anđelima“" (Rilke 1975b: 721).

Na tom putu ne samo da padaju u oči mogućnosti jezika u oblikovanju himničkih formula, iskričavih antiteza, lirskog poleta, nego i unutarnja prostranost, metafizička ustreptalost. Nije primećen ni Rilkeov uticaj na Eliotovu pesmu Bernt Norton (Burnt Norton), u kojoj 
autor Četiri kvarteta (1935) unosi Rilkeovu nemačku reč „Erhebung“ (Erhebung without motion) u gotovo istovetan kontekst uzdizanja nad čulnim datostima (Eliot 1974: 191-192) - u smislu „elevation“ ili, šire gledano, kao „exaltation“, a to znači: kao uzdizanje od objektivnog ka apsolutnom duhu, ili, kako Hegel kaže, ka istinski opštem (Pannenberg 1996: 265).

Ali stvarni smisao prizivanja anđela kod Rilkea je ipak jednostavniji. To je vapaj individualizma za oslobođenjem ličnosti. Onaj isti strasni polet protiv svevlašća spoljašnjeg sveta kome se suprotstavljaju - dve protivrečne slike duše.

Platonska, beživotna ideja duše ista je kao u evropskom baroku. To je mehanička lutka, marioneta. Ona se može shvatiti doslovno: perike, zavrnuti rukavi - sve je bilo povezano žicom (Friedell 2012: 381). Otuda upečatljiva slika lirskog subjekta u Četurtoj elegiji: „Želim da podnesem njen trup i žice i njen lik što je od pukog izgleda sazdan“ (Rilke 1975b: 698). Sada duša ponovo postaje nevidljivi fluid u praznom kostimu povezanom žicama. Ali u njenu suštinu ne može se proniknuti do kraja. Može se samo naslutiti: ne postoje individue, postoje samo lutke koje se pokorno kreću u krugu mehaničkih navika. Tu se lagano odmotava nit prema estetici Oskara Vajlda: „Kada čovek dela, on je marioneta, kada opisuje, on je pesnik“ (Wilde 1994: 1122).

Iz toga je, međutim, proizašla i stilizacija na sceni. Lirsko ja vidi sebe pred lutkarskom pozornicom. Uvereno je da posmatra „lažnu“ scenu i sve što ukazuje na njenu banalnost, ali je ipak posmatra fokusirano. To posmatranje je tako intenzivno, da se na kraju „mora“ pojaviti anđeo i podići uvis sve lutke - poput skrivenog animatora koji ih koncima pokreće i oživljava. Sada su, međutim, lutka i anđeo ponovo razdvojeni kao - telo i duša. „Lutka i anđeo: tek će ovo biti konačno pozorje“. To je trenutak, kaže se dalje u pesmi, kada će se konačno sastati ono što mi neprestano odeljujemo. Tek ce se onda splesti „venac celog bitisanja“; tek ce onda igrati i „anđeo nad nama“ (Rilke 1975b: 698-699). Ideja ostvarenja ličnosti, prelaska u više sfere postojanja sliva se, otuda, s mislima o jedinstvu i gravitaciji, o celovitosti i ravnoteži, o - „unutarnjem prostoru sveta“.

To su dva lica sveta i dva lica duše, jer duša nipošto nije samo ono što Rilke cinično-retorički varira u jednoj pesmi bez naslova iz 1897: „Zar zovete dušom ono što u vama plašljivo zvoni kao zvuk praporaca?" I odmah odgovara: ne, ali nije duša ni neka muzikom izazvana ustreptalost. Nije ni ono što moli i umire u ,večernjem tamjanu gotskih katedrala“. Ona hoće dalje, u svet, s delićem „večnosti u grudima“ (Rilke 1975a: 107). 
Sasvim je drugačija duša anđela koji bi „zgazio bez traga“ ceo taj prizemni vanjski „circus mundi“. Svet je prikazan kao „grad patnji“, na kome se „nabiraju rubovi vašara“. Kroz tu nestvarnu scenografiju kreću se neki „pelivani revnosti“, deca koja se igraju i odrasli koji zveče poput gvozdenih meta na strelištu. Teturaju, povode se, hitaju, jer personifikovane šarene cirkuske šatre „radoznalost svaku zovu“ „mâme“, bubnjaju i trešte (Rilke 1975b:722). Plakati hvale pivo marke „Besmrtnost“ („Todlos“), ali tek tamo, iza neke pregrade, „odmah pozadi“, tamo se nalazi besmrtna stvarnost (isto), ona prava i jedina, a to je - onostranost, $\mathrm{u}$ kojoj će se odškrinuti vrata što vode u pomenuti „unutrašnji prostor sveta“.

Kao pred ulazom u čuveno „Magično pozorište“ sa natpisom „Samo za ludake“ u Heseovom Stepskom vuku, anonimni posetioci Rilkeovog cirkusa postavljaju unapred scenu za svoj mogući život. Jedva još gospodareći svojim čulima, imuni na uzvišenije oblike lepote, oni unapred preživljavaju u svojoj fantaziji budućnost ,životnog cirkusa“ punog zaslepljujućih boja kakvih nema u stvarnosti koja ih okružuje.

Cirkus i lutkarsko pozorište. Oni su „poput dečaka s razrokim okom“ koji vidi dvostruko i tako lažno razlikuje. Tako bar kaže Rilkeov stih u Četurtoj elegïj: „Knabe mit dem Schielauge“ (Rilke 1975b: 698). Da bi se razjasnila ova „razrokost“, ovaj raskorak u poimanju, potrebno je potražiti stvarni koren Rilkeove ideje sveta kao cirkuske i marionetske igre. Njena osobenost izaziva nesporazume i već na prvi pogled ostavlja u nedoumici. Jednim svojim delom taj koren se nesumnjivo nalazi u razmišljanjima Hajnriha fon Klajsta. U ogledu „O marionetskom pozorištu“ (1810), pruski dramatičar bio je pod uticajem tada aktuelnih učenja o pokretima i kinetičkim modelima zasnovanim na postavkama Lajbnicove i Njutnove fizike.

Klajst je razvio „teoriju pokreta“ smeštenu negde između poezije i mehanike, fizike i metafizike. Dva lika, baletski igrač i narator, razmenjuju o tome misli u razgovoru podeljenom na epizode. Pravi vatromet njihovih ideja o fizičkom i intelektualnom „kapacitetu igre“, moguće je - zahvaljujući Klajstovom jezgrovitom pojmu „slika pokreta" (Bewegungsbild) - najpre razvrstati, a potom sažeti u duhu Rosinija: prima la danza, dopo le parole.

Klajst najpre postavlja pitanje šta biva sa čovekom, ako mu duša nije na svom mestu, ako se krije u kičmi ili čak - u laktu. Takvog poremećaja mentalne statike lišena je mehanička lutka, budući da nema ni dušu ni svest. Ako je ova prva teza samo originalna, sledeća je već paradoksalna. Ona glasi da je pokretna lutka simbol savršene gracioznosti. Poseduje sva tri neohodna elementa: skladnost proporcija, 
pokretljivost i lakoću. Nadalje, ona je simbol „prirodnosti“, za razliku od živog čoveka, od akrobate ili baletana koji poseduju - svest. Savršenu gracioznost, drugim rečima, ima samo neko ko se ponaša sasvim neopterećeno i nesvesno, poput deteta, zatim neko ko nema nikakvu svest, poput marionete, i najzad onaj koji je ima u nekom beskonačnom i nama nedokučivom, nespoznatljivom smislu, to jest - Bog.

Ne treba, ipak, verovati omiljenoj tezi da je ovde Klajst razvio neku primernu teoriju pokreta koja je bila ispred svog vremena. Naprotiv, sva učenja Klajstovog doba, sve teorije o svesnoj i nesvesnoj delatnosti u smislu Mesmera, Ritera, Šuberta i magičnog idealizma, koji tvrdi da isti zakoni vladaju u moralnom i fizičkom svetu, slili su se ovde u jedinstvenu teoriju. Pokreti kao pesnička metafora, kao „Bewegungsbild“, prenose svoje značenje u širokom krugu: od konvencionalne slikovnosti do afirmacije osnovnih vrednosti i kriterijuma saznanja o autentičnom bivstvovanju. Taj se krug puni mistikom vitalista i verovanjem u čudesne moći kod romantičara. I oni su svoju pretpostavku tražili kako u fizikalnom obrazloženju, tako i u okultizmu i mesmerizmu. Našli bi je u „animalnom magnetizmu, hipnotičkom snu ili [...] u nehotičnoj clairvoyance 3 mesečara" (Walzel 1908: 65).

Tek se u ovom kontekstu razotkriva i čija je ona strana, nevidljiva, „nikad zadovoljna volja“ iz Pete elegije, čija je tajanstvena sila što pokreće akrobate, baca ih, „vitla i u čvorove svija“. Ta volja je, u stvari, volja onog koga Andrić naziva „Neko ili nešto“, volja skrivenog lutkarskog majstora, demijurga koji sve pokreće nevidljivim koncima.

Nastojeći da na svoj poetski način dokaže kako se iza zavese ovog čudnog spektakla kriju zabluda i životna laž, Rilke genijalno koristi ovu predstavu. Njegove misli i slike takođe poskakuju u stihovima kao zadihani harlekini u šarenim kostimima. On prebacuje silogizme u haotičnom neredu, ili nekom svom redu, pokazujući kako je cirkuski artizam najviše svedočanstvo sopstvene negacije.

A kada u istoj elegiji, u ključnom trenutku, Rilkeov lirski subjekt postavi čuveno pitanje: „Ko još sa strepnjom nije sedeo pred zavesom svog srca?" (Rilke 1975b: 697) - osećamo da je pred nama literarna kontrafaktura. Neka mračna varijacija na temu šaljivih romantičarskih marionetskih i harlekinskih igara što prerano podižu zavesu ili nas neočekivano vode iza spuštene zavese i razbijaju pozorišnu iliziju, otkrivajući, ironično, stvari kojima je pristup zabranjen.

Jer, kad se u elegiji zavesa zaista podigla, pojavio se, u sceni rastanka u vrtu, jedan usamljeni plesač. To je figura fantoma, „poluispunjena maska" kao simbol polovične stvarnosti. Figura brzo nestaje, a sa njom i njeno ambivalentno značenje. Svetiljke su ugašene, gledalac

3 Jasno viđenje, oštrovidost, pronicljivost, vidovitost. 
ostaje sam. Ipak, ostaje nešto, ali nešto što nije ništa: sa pozornice „struji siva praznina vazduha“ (Rilke 1975b: 698). Ta struja nas vodi pred jednu drugu pozornicu čiju zavesu je podigao Franc Kafka.

*

Rilkeova poezija je, unoseći elemente mistike, vilinskom svetlošću obasjala svet cirkusa, varijetea i akrobata kroz slike lutke, anđela, marionete. Ismejala je mehanički život i suprotstavila unutarnji, „suštinski prostor sveta": svet nevidljivog bivstva, svega što je u nama bestelesno, sveto i bogoliko. Što daleko nadmašuje vanjski svet svojim jezikom bogate metaforike i zvuka. I dok Rilke u cirkusu vidi kolektivno iskustvo duhovnosti u znaku religijskih simbola upućenih $\mathrm{u}$ spoznaju bića stvari, dotle Kafka slika spektakl na temelju individualnog ontološkog iskustva, koje u svojim varijacijama ukazuje na istu osnovnu situaciju. Za Andrića, pak, cirkuska arena je simbolički izraz kovitlaca, trajne „estetske neuroze“ iz koje nema izlaza. Cirkus je apokalipsa srednjoevropske duše.

Moglo bi izgledati suviše jednostavno, ako bismo i usamljenički život ovih autora objašnjavali njihovom odbojnošću prema okupljanjima mase, prema spektaklu i „koncentrisanoj društvenosti“ uopšte, te da je, upravo psihološki, cirkus kao simbol masovne zabave ovim čarobnjacima iluzije i deziluzije - inače fasciniranim igrom u svim njenim oblicima - poslužio kao model otuđenosti od prave umetnosti i autentičnog života, iz čega, uostalom, proizlazi estetski imperativ njihovih tekstova: umetnost je laž koja pomaže da se spozna istina. Pa ipak, nema sumnje da je tu odbojnost psihološki oblikovala sprega koju označava naslov knjige Elijasa Kanetija Masa i moć.

Jer, dok je Evropa za mnoge bila magična pozornica intelektualnih projekata i akcija koje su ušle u legendu: Marineti i njegovi skandali, ruski slikari u Minhenu, revolucionarni artisti svih zemalja i ideja u Cirihu, gradu emigrantske umetnosti i politike - Rilke se krio iza njenih kulisa. U dvorcima i otmenim hotelima. Biografi su našli da je tri puta bio spreman da bez zazora kroči u intelektualni svet svoje epohe. Jednom kada je zajedno sa Lu Andreas Salome putovao u Rusiju, gde je sreo Pasternaka, Drošina i vremešnog Tolstoja. Drugi put, kada je u Rodenovom pariskom ateljeu posmatrao dve krajnosti, savršenstvo i ograničenja plastičnih umetnosti, i pritom izvlačio pouke za sopstveni rad. I treći i poslednji put, kada se, zajedno sa Valerijem, našao u društvu okupljenom oko književnog časopisa Francuske nove revije (Nouvelle Revue Française) - ali ipak nigde nije ostajao trajno, uvek se sklanjao, uvek je bežao na marginu, izbegavajući društvene rituale o kojima je njegova majka uzaludno sanjala. 


\section{Literatura}

Andrić, I. (1981a). Sabrana dela. T. X. Beograd (i dr.): Prosveta (i dr.). Andrić, I. (1981b). Sabrana dela. T. XII. Beograd (i dr.): Prosveta (i dr.). Andrić, I. (1981c). Sabrana dela. T. XIV. Beograd (i dr.): Prosveta (i dr.). Andrić, I. (1981d). Sabrana dela. T. XVI. Beograd (i dr.): Prosveta (i dr.). Baudelaire, Ch. (1861). Les Fleurs du Mal. Paris: Paulet-Malssis. Eliot, T.S. (1974). Collected Poems, London: Faber.

Friedell, E. (2012) Kulturgeschichte der Neuzeit. Paderborn: Salzwasser Verlag.

Graff. W (1962). Rilke in the Light of Heidegger. Quebec City: Laval theologique et philosophique, 17, 2, 165-172.

Mukařovský, J. (1948). Kapitoly z české poetiky. Praha: Svoboda.

Nazor, V. (1925/1926). Priče s ostrva, iz grada i sa planine. Zagreb: Matica hrvatska.

Pannenberg, W. (1996). Theologie und Philosophie. Göttingen: Vandenhoeck.

Poulet, G. (1961). Le Metamorphoses de Circle. Paris: Pion.

Rilke, R. M. (1934). Briefe an seinen Verleger, 1909 bis 1925, ed. SieberRilke R., C. Sieber (Hrsg.), Leipzig: Insel-Verlag.

Rilke, R. M. (1937). Briefe I-II. Leipzig: Insel Verlag.

Rilke, R. M. (1975a). Sämtliche Werke in zwölf (12) Bänden (SW). Bd. 1. Frankfurt: Insel Verlag.

Rilke, R. M. (1975b). $S W$ (12). Bd. 2. Frankfurt: Insel Verlag.

Rilke, R. M. (1975c). $S W$ (12). Bd. 3. Frankfurt: Insel Verlag.

Rilke, R. M. / Salomé, L. A (1952). Briefwechsel. Frankfurt: Insel Verlag.

Starobinski, J. (2004). Portrait de l'artiste en saltimbanque. Paris: Gallimard.

Škreb, Z. (1976). O Interpretaciji. Zagreb: Umjetnost riječi, 2.

Walzel, O. (1908). Deutsche Romantik, II. Leipzig: Teubner.

Wilde, O. (1994). The Critic as Artist. The Complete Works of Oscar Wilde. Glasgow: Harper Collins. 
Slobodan K. Grubačić

Universität Belgrad, Philologische Fakultät

\section{Der Orpheus aus Prag: Puppe und Engel in der Dichtung R. M. Rilkes}

$$
\text { - Zusammenfassung - }
$$

Die verschlungenen Schriftzeichen der Intertextualität, um einen Ausdruck von Handke zu paraphrasieren, bewegen die Analysen dieses Beitrags. Zugleich ist die Verfahrensweise komparatistisch. Die Duineser Elegien, die von Rilke selbst als seine gewaltigste dichterische Leistung angesprochen werden, sind vom Sturm einer kulturgeschichtlichen Inspiration emporgetriebene Gedankentrümmer. Sie kreisen um das Rätsel vom Sinn des Lebens. Einsam ist der Mensch; nirgends schliesst sich der Kreis. Die Sonette an Orpheus variieren ähnliche Gedanken anhand der Symbole, welche das Bild der Puppe mit „unsichtbaren Engeln” in Verbindung setzen.

Schlüsselwörter: Artisten, Puppen und unsichtbare Engel; Begriff der ästhetischen Sinnlichkeit; der Weltinnenraum; Rilkes plastische Einbildungskraft; diverse Verwandlungsmodi: Formen des Andersseins; Kleists Bewegungsbilder; Zirkus-Bild als Apokalypse der europäischen Seele. 